\title{
THE EFFECTS OF WORD OF MOUTH AND SALES PROMOTION ON PURCHASING DECISION FOR DREAMLAND DECORATION
}

\author{
Cynthia Anggraini, Tina Melinda \\ Faculty of Business Management, Ciputra University, Surabaya
}

\begin{abstract}
Business development in Indonesia grows rapidly, especially in trade and service field. Due to the economy growth, service industry must be more creative and innovative in creating products, one of them is decoration service. Dreamland Decoration is the company in service field that was established in 2014. Dreamland Decoration accepts orders such as table setting, sweet corner, birthday surprise with unique theme and creative design. This research is done to found out the influence of word of mouth and sales promotion on consumer purchasing decision in using service of Dreamland Decoration. This research uses quantitative method and multiple regression analysis model by involving Dreamland Decoration customers as 80 respondents then is processed by using SPSS 22. The result of this research that has been done states that word of mouth and sales promotion have positive influence on consumer decision in using Dreamland Decoration service.
\end{abstract}

Keywords: word of mouth, sales promotion, service industry, purchasing decision

$\mathrm{B}$ usiness development in Indonesia, especially trade and service businesses, are growing rapidly. In this increasing economic growth, service industry must become more creative and innovative in creating products. Service industry is industry that conducts economic activities and produces products with added value or higher benefits. Industrial service is included in this kind of industry (Yasin \& Yanuarisma, 2016).

The existence of modern competition makes companies of similar industry try to offer their products, resulting in business competition to show their product superiority, including decoration services. The wider the variety of products in service industry, the bigger the business opportunity this industry offers. Dreamland Decoration is one of service industry that experiences this phenomenon, where more and more service industries entering the competition.

\footnotetext{
*Corresponding Author.

e-mail: tina.melinda@ciputra.ac.id
}

Dreamland Decoration is a service industry that accepts orders like table setting, sweet corner, and birthday surprise with unique theme and creative design.

The growing number of competitors motivates Dreamland Decoration to be more active in doing marketing in order to increase and stabilize profits for company cash. Promotion activities done by Dreamland Decoration to increase its sales so far are shown in Table 1.

Table 1 Promotional Activities of Dreamland Decoration

\begin{tabular}{|c|l|l|}
\hline $\begin{array}{c}\text { Variables of } \\
\text { Marketing } \\
\text { Promotion }\end{array}$ & $\begin{array}{l}\text { Promotional Activities of } \\
\text { Dreamland Decoration }\end{array}$ & \multicolumn{1}{|c|}{$\begin{array}{c}\text { Results of } \\
\text { Promotional } \\
\text { Activities }\end{array}$} \\
\hline Discount & $\begin{array}{l}\text { Dreamland Decoration } \\
\text { gave discount or reduced } \\
\text { fare when customers buy } \\
\text { in certain amount. }\end{array}$ & $\begin{array}{l}\text { Visitors asked about } \\
\text { services Dreamland } \\
\text { Decoration offers. }\end{array}$ \\
\hline Exhibition & $\begin{array}{l}\text { Dreamland Decoration } \\
\text { joined mini exhibition, } \\
\text { car free day held by } \\
\text { Ciputra University. }\end{array}$ & $\begin{array}{l}\text { Visitors knew the } \\
\text { business and were } \\
\text { interested to visit the } \\
\text { stand just to find } \\
\text { more information. }\end{array}$ \\
\hline
\end{tabular}

Source: Data processed

Based on the promotional activities done, customers found about Dreamland Decoration 
Cynthia Anggraini \& Tina Melinda / The Effects of Word of Mouth and Sales Promotion on Purchasing Decision

for Dreamland Decoration / JEE, Vol. 7, No. 1, March 2018, pp 19-26

and their products from discounts and exhibitions, yet the promotional activities done were not optimal yet to increase the marketing performance of Dreamland Decoration, fortunately Word of Mouth could increase the sales promotion. Word of Mouth becomes one of marketing endeavors that can make customers recommend, talk about, promote, and sell products to other prospective customers.

Wijaya and Paramita (2014:12) say that Word of Mouth plays a significant role in consumer's purchasing decisions and in shaping customers' behavioural patterns. Besides that, sales promotion is also one factor that can influence purchasing decision. This statement is proven by the results of preliminary interviews, revealing that ads and events can improve purchasing decisions. Tjiptono and Chandra (2012: 367) add that sales promotion is a form of direct persuasion to stimulate product purchase or increase number customers' purchases.

\section{Word of Mouth}

Sari (2016) states that Word of Mouth communication is a personal communication between customers with others. Communication with Word of Mouth tends to be more quickly accepted. Wahyuni et.al., (2016) suggests that Word of Mouth is different from other sources of information, since people will usually assume that Word of Mouth is more reliable than other marketings. In relation to this, Sernovitz (in Carissa, 2017) explains four things to be done to make others talk about products or services through Word of Mouth:

1. Be Interesting

2. Earn Trust and Respect

3. Make People Happy

4. Make It Easy

\section{Sales Promotion}

Sales promotion by Lamb et al., (in Natalia \& Mulyana, 2014) is a marketing activity that offers product by emphasizing its value, while Tjiptono (in Wauran \& Poluan, 2016) states that sales promotion is a diverse form of direct marketing to encourage product and service purchase and can increase amount of goods or services purchased by customers. Sales promotion techniques are divided into two parts, namely discounts and exhibitions.

Sutisna (in Natalia \& Mulyana, 2014) lists the indicators of discount as follows:

1. Discount gives attention;

2. Discount is appealing;

3. Discount encouges to make purchase.

Furthermore, Sutisna (in Natalia and Mulyana, 2014) lists the indicators of exhibitions as follows:

1. Exhibition gives attention;

2. Exhibition is appealing;

3. Exhibition encourages to make purchase.

\section{Purchasing Decision}

Farli and Tielung (2015: 1109) explain about purchasing decision as a process to evaluate two or more alternative options and choose one of them before deciding to purchase a product. Adilang et al., (2014) adds that purchasing decision is a concept of customer's behavior in deciding to use a certain service or product and therefore make product purchase. Peter and Olson (2013: 162) also explain that there are 5 series of stages in decision making, namely:

1. Problem recognition

2. Search information

3. Alternative evaluation 
4. Buying decision

5. Behavior after purchase

\section{Relationships between Variables}

$\mathrm{H}_{1}$ : The effect of Word of Mouth on customer's purchasing decision

Ahmad et al., (2014) states that Word of Mouth has a significant effect on influence on purchasing decision since customers will be more confident to purchase a product after listening to other people's words. Mahendrayasa (2014) also agrees that Word of Mouth has effect on purchasing decision, since information from others will add more information about that product. From this research, it is assumed that Word of Mouth has significant effect on customer's decision to purchase Dreamland Decoration's product.

\section{$\mathrm{H}_{2}$ : The effect of sales promotion on customer's purchasing decision}

Lamb et al., (in Natalia \& Mulyana, 2014) state that sales promotion is a marketing activity that offers product by emphasizing its value, while Tjiptono (in Wauran \& Poluan, 2016) also agree that sales promotion is a diverse form of direct marketing to encourage product and service purchase. Their statements indicate that sales marketing is one variable that has dominant effect on purchasing decision. From their research, it is assumed that sales marketing has significant effect on customer's decision to purchase Dreamland Decoration's product.

\section{RESEARCH METHOD}

\section{Design}

This research is quantitative in nature. Quantitative as research design is a kind of research that gives accurate, systematic, and structured result. Quantitative research method investigates more complex problems. Sugiyono (2012: 7) claims that quantitative research method is based on positivism philosophy and is used to choose specific sample or population.

\section{Population and Sample}

Research population is a whole research with certain qualities and characteristics determined by researchers to study and draw conclusions (Sugiyono, 2016: 117). In this recent research, the population was all customers who ever purchased Dreamland Decoration service, amounted to 80 people. The samples were chosen using saturated sampling technique. Sugiyono (2014: 68) explains about saturated sampling technique as a technique to take all members of a certain population as samples. So, the sample size for this research was 80 people.

\section{Method of Data Collection}

Primary data is data as reference for researcher to solve research problem. A research must be based on accurate data to get accurate results. Meanwhile, secondary data are data obtained from literature study by reading and retrieving data from references related to research variables. In this research, method of data collection used was by distributing Likertscale questionnaire. Likert scale is a method of measuring attitudes and perceptions by calculating responses of approval and disapproval (Sugiyono, 2012: 93). Likert-scale questionnaire was used to collect data since questionnaire can facilitate the respondents to fill in the questionnaire as expected. The scales used are as follows: 
Cynthia Anggraini \& Tina Melinda / The Effects of Word of Mouth and Sales Promotion on Purchasing Decision for Dreamland Decoration / JEE, Vol. 7, No. 1, March 2018, pp 19-26

1. Strongly Disagree

2. Disagree

3. Neutral

4. Agree

5. Strongly Agree

\section{Method of Data Analysis}

This research used multiple linear analysis as method of data analysis, with two independent variables and one dependent variables. The following is the equation used in this research:

$$
\mathrm{Y}=\alpha+\beta_{1} \mathrm{X}_{1}+\beta_{2} \mathrm{X}_{2}+\varepsilon
$$

Where $\mathrm{Y}$ is for Variable of Purchasing Decision, $X_{1}$ is for Word of Mouth, $\beta_{1}$ is for regression coefficient for Word of Mouth variable, $X_{2}$ is for Sales Promotion, $\beta_{2}$ is for regression coefficient for Sales Promotion variable, $\alpha$ for constant, and $\varepsilon$ for error.

\section{RESULTS AND DISCUSSIONS}

\section{Description of Research Results}

After distributing questionnaires to customers of Dreamland Decoration, it was found that 55 respondents or $68.8 \%$ were female respondents while the remaining 25 respondents or $31.3 \%$ were males, means that the customers of Dreamland Decoration are dominated by women. Next, respondents aged 18 to 23 years were the most respondents in this research, amounted to 31 people or $38.8 \%$ of the total number of respondents. This shows that Dreamland Decoration is more favored by young people and this information can facilitate Dreamland Decoration in determining campaign to the right age target. Later, based on their occupation, the respondents were dominated by students or university students, amounted to 40 people, while the rest of them (26 people) were self-employed. Based on this information, it can be known that customers who use Dreamland Decoration's service are mostly students or university students. It also concludes that the customers of Dreamland Decoration already meet this business' market target, which is customers with range of age from 18 to 23 years old.

\section{Validity and Reliability}

After the data were analyzed, it was found that Word of Mouth variable $\left(\mathrm{X}_{1}\right)$, Sales Promotion variable $\left(\mathrm{X}_{2}\right)$, and Purchase Decision (Y) had significant Pearson Correlation value of 0.000 each. Therefore, all indicators of this study were valid because the significant value of all variables was less than $0.05(\leq 0.05)$. Meanwhile, the tests results of all instruments were also reliable since the Cronbach Alpha value was greater than 0.06 . Word of Mouth variable $\left(\mathrm{X}_{1}\right)$ had value of 0.693 , while Sales Promotion $\left(\mathrm{X}_{2}\right)$ was 0.683 and Purchase Decision $(\mathrm{Y})$ was 0.719 .

\section{Multiple Linear Regression Analysis}

Table 2 Tests Results of Multiple Linear Regression Analysis

\begin{tabular}{|c|l|c|}
\hline \multicolumn{2}{|c|}{ Model } & B \\
\hline 1 & (Constant) & 1,053 \\
\hline & Word of Mouth (x1) & 0,270 \\
\hline & Sales Promotion (x2) & 0,505 \\
\hline
\end{tabular}

Source: Primary Data, Appendices, 2017

The following is an explanation of the analysis result of multiple linear regression equation for this research: 


$$
\mathrm{Y}=1,053+0,270 \mathrm{X}_{1}+0,505 \mathrm{X}_{2}
$$

Where $\mathrm{X}_{1}$ was Word of Mouth, $\mathrm{X}_{2}$ was Sales Promotion, and $\mathrm{Y}$ was Buying Decision.

From the regression equation, it can be seen that the coefficient of Word of Mouth variable was 0.270 , means that for every increase in customers' rating for Word of Mouth variable, then the customers' decision for buying Dreamland Decoration's product increased equal to 0.270 , with assumption that this Word of Mouth variable was constant. Therefore, it shows that Word of Mouth variable has positive effect on the customers' buying decision for Dreamland Decoration.

Later, still on the regression equation, it can be seen that the coefficient of Sales Promotion variable was 0.505 , means that for every increase in customer's rating for Sales Promotion variable, then the customer's decision for buying Dreamland Decoration's product increased equal to 0.505 , with assumption that this Sales Promotion was constant. This shows that Sales Promotion variable also has positive effect on the customers' buying decision for Dreamland Decoration.

\section{Classical Assumption Test}

The normality test result showed the significance value of Kolmogorov-Smirnov test was by 0.200 with the requirement that significance value had to be greater than 0.05 , hence the data were normally distributed, assuring that the regression model produced could be used to draw conclusion. From the multicollineality test results, the VIF value of Word of Mouth and Sales Promotion variables were less $<10$, concluding that no multicollinearity found in this research. Furthermore, heterocedasticity test results showed the significance value of Word of Mouth variable was 0.467 and of Sales Promotion variable was 0.596 . Since the significance value of all independent variables were greater than 0.05 , it can be concluded that there was no heterocedasticity in this research. Meanwhile, linearity test results showed the significance value of $\mathrm{X}_{1}$ to $\mathrm{Y}$ linearity was 0.000 and the significance value of $\mathrm{X}_{2}$ to $\mathrm{Y}$ linearity was 0.000 under the condition than the linearity significance value was less than $0.05(\leq 0.05)$, concluding that there is a linear relationship between Word of Mouth and Sales Promotion as independent variables and Buying Decision as dependent variable.

\section{Model Tests (F Test)}

Table 3 F-Test Results

\begin{tabular}{|c|l|c|c|c|c|c|}
\hline \multicolumn{7}{|c|}{ ANOVA } \\
\hline \multicolumn{2}{|l|}{ Model } & Sum of Squares & df & Mean Square & F & Sig. \\
\hline 1 & Regression & 5,295 & 2 & 2,648 & \multirow{2}{*}{33,953} & \multirow{2}{*}{0,000} \\
\hline & Residual & 6,005 & 77 & 0,078 & & \\
\hline & Total & 11,300 & 79 & & & \\
\cline { 1 - 3 } a. Predictors: (Constant), Word of Mouth, Sales Promotion \\
\hline
\end{tabular}

Source: Primary Data, Appendices, 2017 
Cynthia Anggraini \& Tina Melinda / The Effects of Word of Mouth and Sales Promotion on Purchasing Decision

for Dreamland Decoration / JEE, Vol. 7, No. 1, March 2018, pp 19-26

\section{Hypotheses Tests ( $T$ Test)}

Table 4 T-Test Results

\begin{tabular}{|c|c|c|c|c|c|}
\hline \multicolumn{6}{|c|}{ Coefficient } \\
\hline & & $\begin{array}{c}\text { Unstandardized } \\
\text { Coefficient }\end{array}$ & & & Kesimpulan \\
\hline \multicolumn{2}{|r|}{ Model } & B & $\mathbf{t}$ & Sig. & \\
\hline 1 & & 1,053 & 2,635 & 0,010 & \\
\hline & Word of Mouth $\left(\mathrm{X}_{1}\right)$ & 0,270 & 3,220 & 0,002 & $\mathrm{H}_{1}$ diterima \\
\hline & Sales Promotion $\left(\mathrm{X}_{2}\right)$ & 0,505 & 5,420 & 0,000 & $\mathrm{H}_{2}$ diterima \\
\hline
\end{tabular}

Source: Primary Data, Appendices, 2017

The $\mathrm{F}$ test results showed the significance value was 0.000 under the condition of $F$ test significance value was less than 0.05 , hence, this regression model was appropriate so that Word of Mouth variable and Sales Promotion variable can explain Buying Decision variable.

Table 4 shows the significance value of $\mathrm{t}$ test for Word of Mouth variable was 0.002 and for Sales Promotion was 0.000 . It is seen that the significance values of all t-tests for independent variables were less $0.05(\leq 0.05)$. Therefore, it is concluded that Word of Mouth $\left(\mathrm{X}_{1}\right)$ and Sales Promotion $\left(\mathrm{X}_{2}\right)$ have significant partial influence on Buying Decision for Dreamland Decoration's customers.

\section{Coefficient Analysis of Correlation (R) and Determinant Coefficient $\left(\mathrm{R}^{2}\right)$}

Table 5 Coefficient Tests for Correlation (R) Determinant Coefficient

\begin{tabular}{|c|c|c|c|c|c|}
\hline Model & $\mathbf{R}$ & $\begin{array}{c}\mathbf{R} \\
\text { Square }\end{array}$ & $\begin{array}{c}\text { Adjusted } \\
\text { R Square }\end{array}$ & $\begin{array}{c}\text { Std. Error } \\
\text { of the } \\
\text { Estimate }\end{array}$ & $\begin{array}{c}\text { Durbin- } \\
\text { Watson }\end{array}$ \\
\hline 1 & 0,685 & 0,469 & 0,455 & 0,27925 & 1,921 \\
\hline
\end{tabular}

Source: Primary Data, Appendices, 2017

Table 5 shows the value of correlation coefficient (R) was $68.5 \%$, influenced by Word of Mouth and Sales Promotion on Buying Deci- sion, which means that each variable had strong correlation since the value was closer to 1 , while the rest $31.5 \%$ was influenced by other unmeasured variables. The $\mathrm{R}$ Square value $\left(\mathrm{R}^{2}\right)$ value of determinant coefficient was 0.469 or $46,9 \%$, influenced by Word of Mouth and Sales Promotion on Buying Decision, while the rest $53.1 \%$ was influenced by other unmeasured variables outside this research.

\section{Tests Results}

\section{Simultaneous}

Word of Mouth $\left(\mathrm{X}_{1}\right)$ and Sales Promotion $\left(\mathrm{X}_{2}\right)$ simultaneously had significant effects on Buying Decision of Dreamland Decoration customers. This is proven by the F-test results, where the significance value of both variables was 0.000 under the condition that the value was $\leq 0.05$.

Meanwhile, the results of correlation coefficient $(\mathrm{R})$ showed a considerable effect, which was 0.685 or $68.5 \%$, indicating the relationship between Word of Mouth and Sales Promotion with Buying Decision. The results of determinant coefficient $\left(\mathrm{R}^{2)}\right.$ in Table 4.15 show considerable effect which was 0.469 , also indicating the relationship strength between Word of Mouth and Sales Promotion with Buying Decision. 


\section{Partial}

Partial test using T-test is explained as follows:

\section{Word of Mouth $\left(\mathrm{X}_{1}\right)$}

The significant value of $\mathrm{t}$-test for Word of Mouth $\left(\mathrm{X}_{1}\right)$ was 0.002 (sig. $£ 0.05$ ), so that it is understood that Word of Mouth $\left(\mathrm{X}_{1}\right)$ had a partially significant effect on Buying Decision for Dreamland Decoration customers. This result supports this research's first hypothesis, stating that Word of Mouth had a significant effect on customers' Buying Decision. The first hypothesis was therefore accepted and answered the first problem formulation. This result is also supported by previous researches conducted by Ahmad et.al. (2014) and Basri et.al. (2016), which prove that word of mouth has a significant effect on buying decision.

From the respondents' responses, it is concluded that Dreamland Decoration has interesting design features that attract the customers to decide to buy the product; customers tell others about Dreamland Decoration such as by sharing sample of decoration design before the order was placed, and by suggesting more suppliers for more alternatives in terms of design and accessory to get the best product.

\section{Sales Promotion $\left(\mathrm{X}_{2}\right)$}

The significant value of t-test for Sales Promotion $\left(\mathrm{X}_{2}\right)$ was 0.002 (sig. $\left.\leq 0.05\right)$, concluding that this variable had a partially significant effect on Buying Decision for Dreamland Decoration customers. This result supports this research's second hypothesis, stating that Sales Promotion had a significant effect on customers' Buying Decision. This is supported by previous research conducted from Natalia and Mulyana (2014) who also prove that sales promotion has a significant effect on buying decision.

From the respondents' responses, it is found that discounts given encourage the customers to use Dreamland Decoration services, therefore in the near future Dreamland Decoration will conduct product evaluation in form of choosing interesting theme to attract customers' attention, choosing a perfect location to sell the product such as joining wedding exhibition instead of participating in bazaars held by malls, and keep offering discounts to make customers feel that the price offered remains affordable.

\section{CONCLUSIONS AND SUGGESTIONS}

\section{Conclusions}

After conducting analysis on the effects of Word of Mouth $\left(\mathrm{X}_{1}\right)$ and Sales Promotion $\left(\mathrm{X}_{2}\right)$ on customers' Buying Decision for Dreamland Decoration, there are several conclusions that can be offered:

1. Word of Mouth $\left(\mathrm{X}_{1}\right)$ has significant effect on Buying Decision ( $\mathrm{Y})$.

2. Sales Promotion $\left(\mathrm{X}_{2}\right)$ has significant effect on Buying Decision ( $\mathrm{Y}$ ).

Therefore, this research proves that the independent variables measured have significant effects on the dependent variable.

\section{Suggestions}

\section{For the Company}

1. Dreamland Decoration must keep the discounts to make customers feel that the price offered by the company stays affordable.

2. Dreamland Decoration can request their clients to share their testimony when using the product on their instagram. 
Cynthia Anggraini \& Tina Melinda / The Effects of Word of Mouth and Sales Promotion on Purchasing Decision for Dreamland Decoration / JEE, Vol. 7, No. 1, March 2018, pp 19-26

\section{For Future Research}

It is suggested to consider measuring other variables (i.e. service quality and price) that may have effects on buying decision.

\section{BIBLIOGRAPHY}

Adilang, Arthur, Oroh. S.G., \& Moniharapon, S. 2014. Persepsi, Sikap, dan Motivasi Hedonis terhadap Keputusan Pembelian Produk Fashion Secara Online. Jurnal Riset Ekonomi, Manajemen, Bisnis, Akuntansi "Pengaruh Citra Merek dan Word of Mouth terhadap Keputusan Pembelian Konsumen, Vol.2, No.1.

Ahmad. N. 2014. Impact of Word of Mouth on Consumer Buying Decision. European Journal of Business and Management, Vol.6, No.31.

Basri, N.A.H., Ahmad, R., Anuar. F.I., Ismail, K.A. 2016. Effect of Word of Mouth Communication on Consumen Purchase Decision: Malay Upscale Restaurant. Department of Culinary Arts and Gastronomy, Faculty of Hotel and Tourism Management, Universiti Teknologi MARA.

Carissa, Riri. 2017. Pengaruh Dimensi Service Cape Terhadap Word of Mouth (Studi pada Waroeng Steak and Shake di Kedaton Bandar Lampung). Fakultas Ekonomi dan Bisnis.

Farli \& Tielung, M.V. 2015. Pengarub Citra Merek, Kualitas Layanan dan Lokasi Terhadap Keputusan Konsumen Menggunakan Jasa Salon Heasquarters Manado Town Square, 3(1), 1106-1116.

Mahendrayasa, A. 2014. Pengarub Word of Mouth terhadap Minat Beli serta Dampaknya pada Keputusan Pembelian (Survey pada Mahasiswa Pengguna IM3) Fakultas Ilmu Administrasi Universitas Brawijaya. Malang: Fakultas Ilmu Administrasi Universitas Brawijaya.
Natalia. P. dan Mulyana. M. 2014. Pengaruh Periklanan dan Promosi Penjualan terhadap Keputusan Pembelian. Jurnal Ilmiah Manajemen Kesatuan, Vol. 2, No. 2.

Peter, Paul J. dan Jerry C. Olson. 2013. Perilaku Konsumen dan Strategi Pemasaran. Jilid 1 Ed. 9. Dialih Bahasakan oleh Diah Tantri Dwiandani. Jakarta: Salemba Empat.

Sari. F.P. 2016. Pengaruh Harga Citra Merek dan Word of Mouth terhadap Keputusan Pembelian Konsumen. Jurnal Ilmu dan Riset Manajemen, Vol. 5, No. 6.

Sugiyono. 2012. Metode Penelitian Kuantitatif Kualitatif dan RひDD. Bandung: Alfabeta

Sugiyono. 2014. Metode Penelitian Kuantitatif Kualitatif dan R\&DD. Bandung: Alfabeta

Sugiyono. 2016. Metode Penelitian Kuantitatif Kualitatif dan R\&D. Bandung: Alfabeta

Tjiptono, F. \& Chandra, G. 2012. Pemasaran Stratejik Edisi 2. Yogyakarta: Penerbit Andi. Wahyuni, S., Fitriani, N., Nainggolan, T.B. 2016. Does Service Quality of Customer Support Influence Customer Satisfaction and Word of Mouth? A Case Study at Amadeus Indonesia. International Journal of Advanced Research, Vol. 4, No. 2, 397-404.

Waruan. P., dan Poluan. J.G. 2016. Pengaruh Promosi Penjualan dan Servicescape Terhadap Impulse Buying Dengan Shopping Emotion Sebagai Variabel Intervening. Jurnal Berkala Ilmiah Efisiensi, Vol. 16. No. 4.

Wijaya, T. dan Paramitha, E.L. 2014. Pengaruh Electronic Word of Mouth terhadap Keputusan Pembelian Kamera DSLR. Jurnal Pemasaran, 2(1).

Yasin, M.Z. dan Yanuarisma, I. 2016. Sinergi Industri dan UMKM berbasis Kelembagaan dalam Meningkatkan Daya Saing Industri Nasional: Skema Implementasi dan Tranmisi. Jurnal Ilmu Ekonomi Terapan. 